\title{
A Micromethod for the Analysis of Cryoglobulins Via Laser Nephelometry: Evaluation and Comparison to C1q Binding Activity in Autoimmune Diseases in Pediatrics
}

\author{
LILY C. YANG, ${ }^{(36)}$ MICHAEL E. NORMAN, AND ROBERT A. DOUGHTY \\ Department of Pediatrics, University of Pennsylvania School of Medicine and The Children's Hospital of Philadelphia, \\ Philadelphia, Pennsylvania, USA
}

\section{Summary}

Quantitative determinations of cryoglobulins (IgG, IgA, IgM, and $\mathrm{C} 3$ ) were performed by a laser nephelometry microtechnique on 250 serum samples from a group of pediatric patients suspected of having immune complex-mediated disorders. Approximately $50 \%$ of these samples were cryoglobulin positive. Patients with cryoglobulins were examined as three separate groups: systemic lupus erythematosus, presumptive autoimmune disorders, and chronic bacterial or viral infections. Nearly all of these patients have mixed cryoglobulins. The relation of cryoglobulinemia with serum hypocomplementemia and renal involvement was examined in a group of systemic lupus erythematosus patients. High levels of cryoglobulins were found in patients with hypocomplementemia and anti-DNA antibodies without clinical evidence of nephritis. Highly significant correlations were observed between $\mathrm{Clq}$ binding activity, presence of cryoglobulins, and serum hypocomplementemia in systemic lupus erythematosus patients. Only $60 \%$ of the cryoglobulin positive samples had immune complex demonstrable by $\mathrm{Clq}$ binding. Cryoglobulin analysis using the laser nephelometry microtechnique permits screening of pediatric patients for the presence of immune complex, permits detection of low levels of cryoglobulins, allows quantitative determination of the specific immunoglobulin classes in the precipitate, and requires only a very small amount of blood suitable for the pediatric population.

\section{Speculation}

Cryoglobulins may represent circulating immune complex (IC) in diseases where IC-mediated pathogenesis is implicated. In systemic lupus erythematosus, presence of anti-DNA antibodies, C1q binding activity and hypocomplementemia was accompanied by elevated cryoglobulins. It is possible that in these patients, the presence of IC detected by $\mathrm{Clq}$ binding activity is reflected by elevated cryoglobulins. When considering autoimmune diseases in general, cryoglobulin analysis via laser nephelometry may be more sensitive than $\mathrm{C} 1 \mathrm{q}$ binding in detecting IC, some of which may not bind complement. This technique could easily be utilized as a screening, diagnostic, and perhaps prognostic tool for children with autoimmune diseases.

Cryoglobulins were first described by Lerner and Watson (13) as proteins which undergo reversible precipitation in the cold. Most of these cold, insoluble proteins are immunoglobulin (Ig) and complement components $(9,14)$ which may represent constituents of antigen-antibody complexes. They have been implicated in the pathogenesis of vasculitis, glomerulonephritis, and collagen- vascular diseases $(21,25,29,31)$. In some cases, rheumatoid factor (15), doubled-stranded DNA (30), renal tubular epithelial antigens (27), and hepatitis antigen (18) have been identified as components of the cryoglobulin complexes. However, the detection of cryoglobulins in the serum of some patients with presumed immune complex (IC) diseases (e.g., based upon other criteria such as immunofluorescence and electron microscopy of biopsy specimens) has been unsuccessful.

Circulating soluble IC have been found in patients with such diverse diseases as bacterial infections, malignancies, inflammatory bowel diseases, and autoimmune connective tissue disorders $(16,19)$. Inasmuch as many IC's bind complement through activation of the classical pathway (20), several IC assays have been developed based upon Clq binding to the IgG or IgM antibody in the complex and have been used to study patients with rheumatoid arthritis, Sjögren's syndrome, systemic lupus erythematosus (SLE), chronic persistent hepatitis, and various forms of glomerulonephritis (22).

Due to the importance of cryoglobulins reflecting the presence of circulating IC in a number of diseases sited above in adults, we evaluated the significance of cryoglobulins in a group of pediatric patients. Traditionally, cryoglobulins are quantitated by radial immunodiffusion requiring 20 to $50 \mathrm{ml}$ of whole blood. The large volume of blood required for this analysis is prohibitive in children, which led us to develop a microtechnique suitable for the pediatric population. Serum specimens from patients suspected of having IC-mediated disorders were analyzed for the presence of cryoproteins by the laser nephelometer. Review of the diagnosis of patients with positive cryoglobulins revealed SLE, assorted presumptive autoimmune diseases characterized by chronic inflammatory pathogenesis (e.g., Sjögren's syndrome, Raynaud's syndrome, etc.), and chronic bacterial and viral infections.

To determine whether cryoglobulin-positive samples reflected circulating IC detectable by the $\mathrm{Clq}$ binding assay, aliquots of the same serum specimen were analyzed by both assays in a group of SLE patients. Measurement of cryoglobulins and circulating IC were correlated with other parameters of disease activity including serum complement, Ig, antinuclear antibodies, anti-DNA antibodies, and clinical evidence of nephritis. Results indicate that the presence of cryoglobulins correlates well with other parameters of disease activity in SLE.

\section{MATERIALS AND METHODS}

Two hundred fifty serum samples from patients with clinical symptoms suggestive of IC-mediated disorders were analyzed for the presence of cryoglobulins. Of the cryoglobulin-positive pa- 
tients, 28 sera were from patients with SLE (group 1), 67 were from patients with presumptive autoimmune diseases (group 2), and 16 were from patients with chronic bacterial or viral infections (group 3). Presumptive autoimmune disease patients include chronic panniculitis, progressive systemic sclerosis, Kartagener's syndrome, recurrent stomatitis, juvenile rheumatoid arthritis, Steven's-Johnson syndrome, idiopathic thrombocytopenia, Behçet's syndrome, acute glomerulonephritis, Raynaud's syndrome, nonmalignant pancytopenia, and Sjögren's syndrome. These patients have pathologic changes in target organs including lymphocytic infiltration, tissue autoantibodies, and deposition of IC as judged by immunofluorescence microscopy. The "chronic infections" group includes patients with subacute bacterial endocarditis and viral and bacterial meningitis where the infectious agent was isolated. We studied 13 otherwise healthy children undergoing elective tonsilectomy to determine if elevated cryoglobulins were found in "sick" patients without autoimmune or chronic infections (e.g., disease controls). Thirteen normal hospital personnel were used to establish levels of cryoglobulins in healthy controls. In 18 of 28 of the SLE patients, simultaneous measurements of $\mathrm{Clq}$ binding, serum Ig, C3 complement, and total hemolytic complement were performed.

\section{ISOLATION OF CRYOGLOBULINS}

Serum for cryoglobulin analysis was separated from 2 to $5 \mathrm{ml}$ of whole blood drawn into prewarmed test tubes and clotted for $1 \mathrm{hr}$ at $37^{\circ} \mathrm{C}$. Serum was isolated by centrifuging twice to remove red blood cells at $37^{\circ} \mathrm{C}$. Serum volume was recorded, and specimen was refrigerated at $4^{\circ} \mathrm{C}$ for 4 to 6 days. Cryoprecipitates were washed eight times in cold phosphate-buffered saline by centrifuging at $4^{\circ} \mathrm{C}, 1200 \times g$ for $10 \mathrm{~min}$. The final precipitates were solubilized in $0.2 \mathrm{ml}$ of phosphate-buffered saline and kept at $37^{\circ} \mathrm{C}$ for at least $30 \mathrm{~min}$ prior to quantitations. Insolubilized material was detected in the sample blank and subtracted from the test specimen. In most instances, the sample blank demonstrates insignificant light scattering (e.g., insignificant insolubilized material).

\section{QUANTITATIONS OF Ig AND COMPLEMENT COMPONENTS}

All quantitations of $\operatorname{IgG}, \operatorname{IgA}, \operatorname{IgM}$, and $\mathrm{C} 3$ were made with the Hyland Laser Nephelometer PDQ LAS-R (Hyland Laboratories, Costa Mesa, CA) by methods previously described (6). Monospecific antiserum reagents and reference standards for LAS-R were obtained from Hyland Laboratories. In all the test samples, a solution of polyethylene glycol/saline (40 and $9 \mathrm{~g} / \mathrm{liter}$ ) was used to enhance precipitation. Ten serial dilution reference points instead of the conventional six points were used to establish the standard curve. For serum specimens, $1-\mu \mathrm{l}$ aliquots were added to $1 \mathrm{ml}$ of appropriate antiserum preparations. An additional $1 \mu \mathrm{l}$ was used for blanks to correct for background light scattering along with saline and antibody blanks. IgG samples were read after $20 \mathrm{~min}$ incubation at room temperature. $\operatorname{IgA}, \operatorname{IgM}$, and $\mathrm{C} 3$ were read within 3 to $4 \mathrm{hr}$.

For cryoglobulin analysis, $25-\mu$ l aliquots of solubilized cryoproteins in PBS were used. To increase sensitivity, a low-level reference curve was constructed by expanding the last seven reference points to full scale of 190 relative light-scattering units. The sensitivity of the low reference curve for $\mathrm{IgG}=0.16 \mathrm{mg} / \mathrm{dl}, \operatorname{IgA}$ $=0.03 \mathrm{mg} / \mathrm{dl}$, and $\mathrm{IgM}=0.02 \mathrm{mg} / \mathrm{dl}$ based on $1 \mu \mathrm{l}$ of serum Concentration of cryoglobulins were read directly from the lowlevel standard curve and expressed as $\mathrm{mg} / \mathrm{dl}$ of original serum.

\section{DETECTION OF IMMUNE COMPLEXES BY CIq BINDING}

Aliquots of serum samples obtained for cryoglobulin analysis were spun down immediately and kept at $-76^{\circ} \mathrm{C}$ until use. All samples were freeze-thawed only once. Clq binding assays were performed according to modification of method by Zubler et al. (34). Normalized Clq binding activity was calculated by subtracting values for the normal control ( $\overline{\mathrm{x}} \pm 2 \mathrm{~S}$.D.) from patient's sera.
$\mathrm{Clq}$ binding activity was considered significant only if it exceeded the $95 \%$ confidence level for normal controls.

\section{DNA BINDING ACTIVITY}

Serum DNA binding activity are measured by a modified Farr technique using Millipore filters $(28) .\left[{ }^{14} \mathrm{C}\right] \mathrm{KB}$-cell DNA $(0.1 \mathrm{uCi} /$ $\mathrm{ug}, 10 \mu \mathrm{g}$, lot 2924) was obtained from Virgo Reagents, Electronucleonics Laboratories, Inc., Bethesda, MD 20014. The Millipore filters were dried and processed for counting in a Packard TriCarb Scintillation Spectrometer.

\section{RESULTS}

Table 1 shows the mean, standard deviations, and ranges of cryoglobulin components concentration for the various groups of patients. Nearly all patients in Groups 1, 2, and 3 have mixed cryoglobulins $(96,90$, and $94 \%$, respectively). Assay for rheumatoid factor was examined in $70 \%$ of all these patients, and all were negative. Patients undergoing elective tonsillectomy showed no $\mathrm{IgG}$ and trace amounts of $\operatorname{IgA}$ and $\operatorname{IgM}(<0.60 \mathrm{mg} / \mathrm{dl})$. Normal adults showed undetectable IgA and low levels of IgG, IgM, and C3.

COMPARISONS OF SLE RENAL INVOLVEMENT, DISEASE ACTIVITY, AND CRYOGLOBULIN LEVELS

Antibodies to native ds DNA (DNA-binding activity) are frequently found in patients with active SLE and often correlated with active nephritis (11). Presence of DNA-binding activity and hypocomplementemia are used in monitoring the clinical course and determining therapeutic efficacy in SLE patients. We examined the relationship between serum DNA binding activities, complement levels, cryoglobulin levels, and clinical nephritis (Fig. 1). SLE patients were divided into four serologic subgroups and further classified by the presence or absence of nephritis as follows:

(1) $\mathrm{HC}+($ hypocomplementemia) and DNA+ (antibodies to ds DNA)

(2) $\mathrm{HC}+$ and DNA-

(3) $\mathrm{HC}-$ and DNA+

(4) $\mathrm{HC}-$ and DNA-

Cryoglobulins were most frequently elevated in $\mathrm{HC}+, \mathrm{DNA}+$ patients, especially those without nephritis. All patients had normal serum Ig except for one with elevated serum IgM where cryoglobulin IgM was also positive. Six SLE samples with negative cryoglobulins were from patients receiving steroid therapy.

\section{COMPARISON OF SERUM AND CRYOGLOBULIN COMPONENTS TO CIq BINDING ACTIVITY}

Quantitative $\operatorname{IgG}, \operatorname{IgA}, \operatorname{Ig} M$, and $\mathrm{C} 3$ in cryoproteins were compared with the quantitative serum Ig and normalized percentage of $\mathrm{Clq}$ binding activity in Table 2 and Figure 2. In our laboratory, $\mathrm{Clq}$ binding activity for normal control sera varied from $7.1 \pm 1.5 \%$ to $11.8 \pm 5.6 \%$ for different $\left[{ }^{125} \mathrm{I}\right] \mathrm{Clq}$ preparations Normalized $\mathrm{Clq}$ binding activity of less than $2 \%$ is considered insignificant. A total of 35 samples from patients with autoimmune diseases was analyzed. Eighty percent (28 of 35$)$ of the samples were cryoglobulin positive, only 17 of 28 had elevated Clq binding activity, the other 11 of 28 had elevated cryoglobulins but negative $\mathrm{Clq}$ binding activity. The remaining 7 patients had negative cryoglobulins and negative $\mathrm{Clq}$ binding activity. For all patients, the probability for departure from independence calculated by the $\chi$-square test was $P=0.075$. However, when SLE patients were analyzed separately as a group, a much closer correlation was observed $(P=0.0002)$.

Serum hypocomplementemia and the presence of complement components in IC have been implicated in the pathogenesis and disease activity in SLE patients (1, 5, 26). Six samples (Table 2, asterisk) had decreased serum C3 levels below $70 \mathrm{mg} / \mathrm{dl}$ and elevated cryoglobulin $\mathrm{C} 3$ as seen in Figure 3. Only three of six samples had markedly elevated levels of cryoglobulins. Samples 
Table 1. Levels of immunoglobulins and BIC in cryoprecipitates

\begin{tabular}{|c|c|c|c|c|c|}
\hline Group & & $\operatorname{IgG}(\mathrm{mg} / \mathrm{dl})$ & $\operatorname{IgA}(\mathrm{mg} / \mathrm{dl})$ & $\operatorname{IgM}(\mathrm{mg} / \mathrm{dl})$ & $\mathrm{C} 3(\mathrm{mg} / \mathrm{dl})$ \\
\hline \multirow[t]{3}{*}{1} & SLE & & & & \\
\hline & Range & $0.10-164.00$ & $0-94.50$ & $0-464.00$ & $0-25.60$ \\
\hline & $\begin{array}{l}\text { Mean } \pm \text { S.D. } \\
n=28\end{array}$ & $23.50 \pm 44.30$ & $6.01 \pm 18.68$ & $39.70 \pm 99.40$ & $2.03 \pm 4.96$ \\
\hline \multirow[t]{3}{*}{2} & Autoimmune diseases & & & & \\
\hline & Range & $0-748.00$ & $0-33.30$ & $0-65.50$ & $0-14.70$ \\
\hline & $\begin{array}{l}\text { Mean } \pm \text { S.D. } \\
n=65\end{array}$ & $22.00 \pm 99.30$ & $2.62 \pm 6.56$ & $9.56 \pm 15.79$ & $4.75 \pm 13.57$ \\
\hline \multirow[t]{3}{*}{3} & Chronic infections & & & & \\
\hline & Range & $0-37.71$ & $0-10.98$ & $0.76-97.80$ & $0-4.05$ \\
\hline & $\begin{array}{l}\text { Mean } \pm \text { S.D. } \\
n=15\end{array}$ & $3.11 \pm 20.50$ & $0.96 \pm 2.69$ & $9.12 \pm 23.79$ & $0.49 \pm 0.99$ \\
\hline \multirow[t]{3}{*}{4} & Tonsillectomy & & & & \\
\hline & Range & 0 & $0-0.60$ & $0-0.59$ & $0-0.44$ \\
\hline & $\begin{array}{l}\text { Mean } \pm \text { S.D. } \\
n=13\end{array}$ & 0 & $0.28 \pm 0.60$ & $0.20 \pm 0.22$ & $0.04 \pm 0.12$ \\
\hline \multirow[t]{3}{*}{5} & Normal adults & & & & \\
\hline & Range & $0-0.14$ & 0 & $0-0.21$ & $0-0.31$ \\
\hline & $\begin{array}{l}\text { Mean } \pm \text { S.D. } \\
n=13\end{array}$ & $0.04 \pm 0.04$ & 0 & $0.06 \pm 0.07$ & $0.08 \pm 0.10$ \\
\hline
\end{tabular}

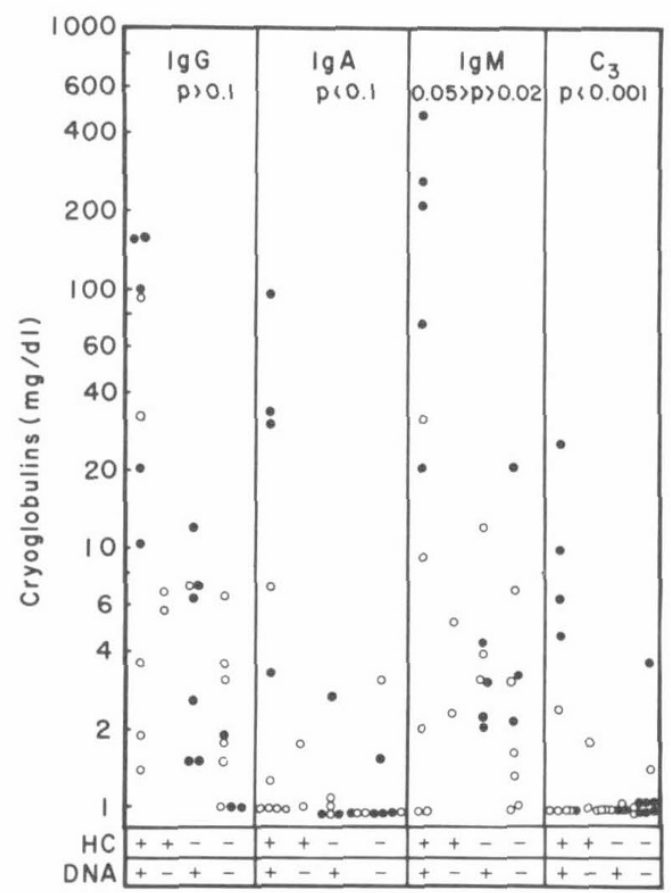

Fig. 1. Comparison of SLE renal involvement, disease activity, and cryoglobulin levels. patients without renal disease; $\bigcirc$, patients with renal disease. Student $t$ test between patients with and without nephritis gives: IgG, $P>0.1 ; \operatorname{IgA}, P<0.1 ; \mathrm{IgM}, 0.05>P<0.02 ; \mathrm{C}_{3}, P<0.001$.

with normal or elevated serum C3 had only low levels of cryoglobulin C3.

\section{DISCUSSION}

Cryoglobulins are thought to consist mainly of Ig representing antigen-antibody complexes. Due to the recent rise of interest in measuring IC in various diseases, cryoglobulin detection has become a potentially important diagnostic and prognostic tool. In our laboratory, cryoglobulin analysis was performed by a sensitive laser nephelometric technique $(4,6,12)$. The low level limits for IgG by radial immunodiffusion is $7 \mathrm{mg} / \mathrm{dl}$ obtained by filling the wells twice, whereas laser nephelometry detects $0.16 \mathrm{mg} / \mathrm{dl}$, approximately a 50 -fold increase in sensitivity. With this improved sensitivity, we found that low levels of cryoproteins are present even in normal subjects.

The association of cryoprecipitates with hypocomplementemia and tissue injury in SLE has been well documented $(1,5,17,26)$. McIntosh et al (17) observed that patients with nephritis had evidence of elevated levels of cryoprecipitates associated with progression of the disease and disappearance with resolution or progression to end stage renal failure. Those authors concluded that detection of cryoglobulins was a better indication of the severity of renal disease than complement. Surprisingly, in our study, SLE patients without nephritis who were anti-DNA antibody positive and hypocomplementemia had a higher incidence of elevated cryoglobulins than those with nephritis. Therefore, elevated cryoglobulins, including complement $\mathrm{C} 3$, may not always reflect the presence of nephritogenic IC.

Cryoglobulins occur in a wide variety of autoimmune diseases other than SLE such as glomerulonephritis (17), chronic active hepatitis (16), Sjögren's syndrome (32), and Raynaud's syndrome (3). Our patients with a variety of presumed autoimmune diseases showed mixed cryoglobulins consistent with the finding of others (3). Clinical remission has been associated with a decrease in cryoglobulin levels in some of our patients (24).

In the rabbit model of acute serum sickness, demonstration of antigen-antibody activity in cryoprecipitates and the association of these insoluble proteins with IC diseases imply an analogy between cryoglobulins and IC $(10,18,19,30)$. In our study, simultaneous measurements of cryoprecipitates and $\mathrm{Clq}$ binding indicate that these two assays are indeed related. The SLE group of patients had a much higher correlation than the other "presumed autoimmune disease" group. However, the presence of cryoglobulins does not correlate as closely to $\mathrm{Clq}$ binding activity 
Table 2. Quantitation of cryoglobulins and Clq binding activity

\begin{tabular}{|c|c|c|c|c|c|c|c|c|c|c|}
\hline \multirow[b]{2}{*}{ Point } & \multirow[b]{2}{*}{ Diagnosis } & \multicolumn{4}{|c|}{ Cryoglobulins (mg/dl) } & \multicolumn{4}{|c|}{ Serum $(\mathrm{mg} / \mathrm{dl})$} & \multirow[b]{2}{*}{$\mathrm{Clq}$ binding } \\
\hline & & $\operatorname{IgG}$ & $\operatorname{Ig} A$ & IgM & $\mathrm{C} 3$ & IgG & $\operatorname{IgA}$ & IgM & $\mathrm{C} 3$ & \\
\hline 1 & SLE & 20.86 & 1.00 & 64.80 & 0.81 & 2172 & 290 & 295 & $11.1^{2}$ & 55.5 \\
\hline 2 & SLE & 7.86 & 1.08 & 12.86 & 1.02 & 2169 & 481 & 170 & 90 & 8.5 \\
\hline 3 & SLE & 5.72 & 0.52 & 2.60 & 0.49 & 960 & 129 & 220 & 99 & 1.5 \\
\hline 4 & SLE & 33.00 & 1.29 & 9.14 & 0.39 & 740 & 132 & 60 & $67^{2}$ & 14.5 \\
\hline 5 & SLE & 1.43 & 0.29 & 0.68 & 0 & 2400 & 310 & 90 & 83 & 13.5 \\
\hline 6 & SLE & 2.58 & 0.17 & 2.43 & 0.21 & 1761 & 355 & 222 & 184 & 12.5 \\
\hline 7 & SLE & 3.20 & 0.28 & 3.12 & 0 & 947 & 112 & 238 & 138 & 1.5 \\
\hline 8 & SLE & 6.44 & 2.72 & 2.08 & 0 & 1130 & 124 & 76 & 102 & 11.5 \\
\hline 9 & SLE & 1.96 & 0.05 & 2.16 & 0.63 & 1431 & 333 & 158 & $23^{2}$ & 45.5 \\
\hline 10 & SLE & 12.67 & 2.67 & 4.34 & 0 & $\mathrm{ND}^{3}$ & ND & ND & 115 & 3.5 \\
\hline 11 & SLE & 156.50 & 34.50 & 255.00 & 9.80 & 1782 & 534 & 230 & $31^{2}$ & 53.4 \\
\hline 12 & SLE & 164.00 & 94.50 & 464.00 & 25.60 & ND & ND & ND & $45^{2}$ & 49.4 \\
\hline 13 & SLE & 10.24 & 3.36 & 21.52 & 6.40 & 2089 & 202 & 151 & $68^{2}$ & 29.4 \\
\hline 14 & SLE & 5.28 & 2.56 & 7.84 & 2.56 & ND & ND & ND & 95 & 0.4 \\
\hline 15 & SLE & 0.81 & 0.18 & 0.53 & 0.02 & 2367 & 234 & 176 & 141 & 7.0 \\
\hline 16 & SLE & 1.89 & 1.54 & 21.40 & 0.08 & 1814 & 507 & $510^{1}$ & 183 & 3.0 \\
\hline 17 & SLE & 1.81 & 0.59 & 3.26 & 0 & 1756 & 278 & 386 & 75 & 7.0 \\
\hline 18 & SLE & 7.08 & 1.10 & 3.93 & 0.10 & 1391 & 433 & 102 & 111 & 5.0 \\
\hline 19 & $\mathrm{AGN}$ & 15.80 & 1.10 & 3.00 & 0.63 & 923 & 205 & 161 & 178 & 0 \\
\hline .20 & $\mathrm{AO}$ & 0.37 & 0.26 & 1.26 & 0.31 & 693 & 174 & 105 & 280 & 0 \\
\hline 21 & SLE & 0 & 0.28 & 5.75 & 2.33 & 1522 & 232 & 174 & 190 & 0.5 \\
\hline 22 & RS & 0 & 0.69 & 1.21 & 0.96 & 1200 & 250 & 109.2 & 270 & 1.5 \\
\hline 23 & JRA & 2.50 & 0.34 & 0.18 & 0.26 & ND & ND & ND & 226 & 0 \\
\hline 24 & LIP & 0.40 & 0.20 & 0.32 & 0.74 & 978 & 4.9 & 183 & 167 & 0.5 \\
\hline 25 & SLE & 0.53 & 0 & 12.70 & 0.32 & 1193 & 1.90 & 217 & 158 & 0 \\
\hline 26 & SS & 0 & 2.60 & 0.04 & 1.08 & 1254 & 95 & 86 & 152 & 0.5 \\
\hline 27 & BMT & 1 & 0 & 5.29 & 0 & 387 & 37 & 53 & & 2.5 \\
\hline 28 & ITP & 0 & 4.48 & 0 & 0 & 1545 & 61 & 264 & 181 & 0 \\
\hline
\end{tabular}

${ }^{1}$ Normalized Clq binding activity calculated by subtracting negative controls $(\bar{x} \pm$ S.D.) from the patient's data for each experiment.

${ }^{2}$ Hypocomplementemic samples.

${ }^{3} \mathrm{ND}$, not done, AGN, acute glomerulonephritis; AO, aseptic osteomyelitis; RS, recurrent stomatitis; JRA, juvenile rheumatoid arthritis; LIP, lymphocytic interstitial pneumonitis; SS, Sjögren's syndrome; BMT, bone marrow transplant; ITP, idiopathic thrombocytopenia purpura.

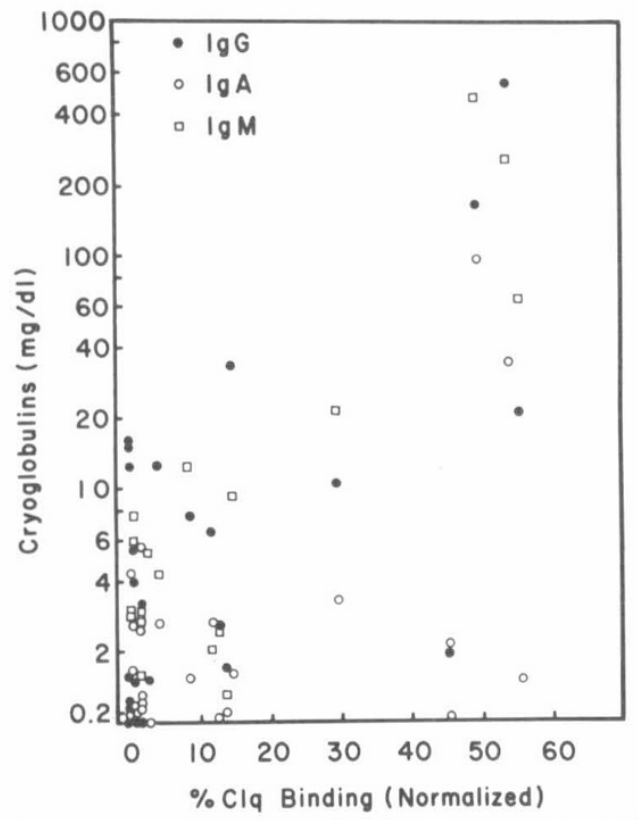

Fig. 2. Comparison of cryoglobulin components to normalized $\mathrm{Clq}$ binding activity.

as one might expect if these two assay systems indeed measure the same type of IC. In our study, the cryoglobulins were positive $40 \%$ more frequent than $\mathrm{Clq}$ binding activity.

The association of hypocomplementemia with elevated $\mathrm{Clq}$ binding activity and $\mathrm{C} 3$ cryoglobulin component were observed

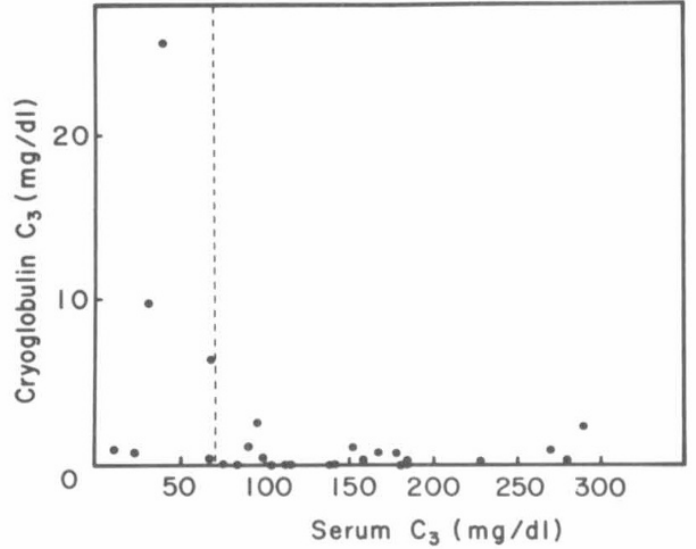

Fig. 3. Comparison of serum and cryoglobulin C3 levels in SLE patients.

in $50 \%$ of the SLE patients. Whether the C3 is being consumed in part due to the formation of precipitable $\mathrm{C} 3 \mathrm{IC}$ and thus plays a pathologic role in tissue damage remains to be investigated.

There are several possible explanations for the poor correlation between $\mathrm{Clq}$ binding activity and the presence of cryoglobulins in autoimmune diseases other than SLE. First, these results may reflect the greater sensitivity of the nephelometric technique. A second possibility is that these two assays detect different types of IC. Another possibility may be the experimental conditions themselves. Due to the heat lability of $\mathrm{Clq}$, the binding activity assay is performed at $4^{\circ} \mathrm{C}$ which may render some soluble IC insoluble. The formation of larger lattices of complex may reduce the 
number of receptors available for $\mathrm{Clq}$ binding. Clq may also bind to aggregates of $\mathrm{IgG}$ formed during freeze thawing of the specimens. Finally, not all IC necessarily bind Clq. In both assays, demonstration of the antigen(s) in question would be of tremendous value. Unfortunately, the unavailability of sensitive assays plus the lack of knowledge of which antigen(s) may be involved make the demonstration of antigen(s) in such complexes very difficult.

Cryoglobulin determination by light scattering may be affected by the nature of the antigen as well as the size of the complexes because larger particles involve greater light scattering. The effect of the sizes and nature of IC upon the sensitivity of this assay is currently being studied; however, this potential variable does not detract from the fact that this assay is able to sensitively detect Ig and complement components present in cryoproteins.

The presence of cryoglobulins can be easily detected in patients with presumed autoimmune or IC-mediated disorders by this microtechnique using laser nephelometry. The presence of cryoglobulins correlates well with IC detected by Clq binding activity in patients with SLE. A strong correlation between presence of cryoglobulins, hypocomplementemia, and anti-DNA antibodies was seen in SLE patients without nephritis. Cryoglobulin determinations may serve as an effective screening technique for the presence of IC in autoimmune diseases in children. The small quantity of serum required in this assay is important in following pediatric populations which cryoproteins may serve as a valuable diagnostic and perhaps prognostic tool.

\section{REFERENCES AND NOTES}

I. Agnello, V., Koffler, D., Eisenberg, J. W., Winchester, R. J., and Kunkel, H. G. Clq recipitins in the sera of patients with systemic lupus erythematosus and other hypocomplementemic states: characterization of high and low molecular weight types. J. Exp. Med., 134: 228s (1971).

2. Bonomo, L, and Demaco, F.: Immune complex cryoglobulinemia in lepromatous leprosy. Clin. Exp. Immunol., 9: 175 (1971).

3. Brouet, J. C., Clauvel, J. P., Danon, F., Klein, M., and Seligmann, M.: Biological and clinical significance of cryoglobulins. A report of 86 cases. Am. J. Med., 57: 775 (1974).

4. Buffone, G. J., Lewis, S., Savory, J., and Hicks, J. M.: Measurement of proteins in serum, urine and cerebrospinal fluid using laser nephelometry, In: F. W. Sunderman: Seminar on Proteins and Proteinopathies. p. 73 (Institute for Clinical Science, Philadelphia, PA, 1977).

5. Christian, C. L., Hatfield, W. B., and Chase, P. H.: Systemic lupus erythematosus. Cryoprecipitation of sera. J. Clin. Invest., 42: 823 (1963).

6. Deaton, C. D., Maxwell, K. W., Smith, R. S., and Creveling, R. L.: Use of laser nephelometry in the measurement of serum protein. Clin. Chem., 22: 1465 (1976).

7. Fillit, H., Van De Rijn, I., Brandeis, W. E., Day, N. K., and Zabriskie, J. B.: Serial studies on circulating immune complexes in post-streptococcal sequelae. Fed. Proc., 37: 2195 (1978).

8. Florin-Christensen, A., Roux, M. E. B., and Arana, R. M.: Cryoglobulins in acute and chronic liver diseases. Clin. Exp. Immunol., 16: 599 (1974).

9. Grey, H., and Kohler, P. F.: Cryoimmunoglobulins. Semin. Hematol., 10: 87 (1973).

10. Griswold, W. R., Hsu, K. C., and McIntosh, R. M.: Cryoprecipitates and immune complex disease in antibody bound ${ }^{131}$ I-labeled BSA antigen after cryoprecipitation in rabbit serum. Proc. Soc. Exp. Biol. Med., 142: 1294 (1973).

11. Hughes, G. R. V.: Frequency of anti-DNA antibodies in systemic rheumatic diseases. Ann. Intern. Med., 83: 464 (1975).

12. Killingsworth, L. M., and Savory, J.: Manual nephelometric methods for immunochemical determination of immunoglobulins IgG, IgA and IgM in human serum. Clin. Chem., 18: 335 (1972).

13. Lerner, A. B., and Watson, C. J.: Studies of cryoglobulins. I. Unusual purpura associated with the presence of a high concentration of cryoglobulins (col precipitable serum globulin). Am. J. Med. Sci., 214: 410 (1947).

14. Linscott, W. D., and Kane, J. P.: The complement system in cryoglobulinemia Interaction with immunoglobulins and lipoprotein. Clin. Exp. Immunol., 2N 510 (1975).

15. Lutra, H. S., McDuffie, F. C., and Hunder, G. G.: Immune complexes in ser and synovial fluids of patients with rheumatoid arthritis. Radioimmunoassa with monoclonal rheumatoid factor. J. Clin. Invest., 56: 458 (1975).

16. McIntosh, R. M., and Grossman, B. J.: IgG, BIC, fibrinogen cryoprotein in acut glomerulonephritis. N. Engl. J. Med., 285: 1521 (1971).

17. McIntosh, R. M., Kaufman, D. B., Kulvinskas, C., and Grossman, B. J.: Cry oglobulins I. Studies on the nature, incidence and clinical significance of serun cryoproteins in glomerulonephritis. J. Lab. Clin. Med., 75: 566 (1970). 18. McIntosh, R. M., Koss, M. N., and Gocke, D. J.: The nature and incidence o
cryoproteins in hepatitis B antigen (HBsAg) positive patients. Q. J. Med., 177 23 (1976)

19. Miani, R. N., and Holborow, E. J.: Detection and measurement of circulating soluble antigen-antibody and anti-DNA antibodies. Ann. Rheum. Dis., 36s: (1977).

20. Müller-Eberhard, H. J., and Calcott, M. A.: Interaction between Clq and gamm: globulin. Immunochemistry, 3: 500 (1966).

21. Noel, L. H., and Yanerva, H.: Complement deposition in the kidney. Adv Nephrol., 4: 37 (1974).

22. Nydegger, U. E., Lambert, P. H., Gerber, H., and Miescher, P. A.: Circulating immune complexes in the serum in systemic lupus erythematosus and in carriers of hepatitis B antigen. Quantitations by binding to radiolabelled Clq J. Clin. Invest., 54: 297 (1974).

23. Ooi, Y. M., Ooi, B. S., Vallota, E. H., First, M. R., and Pollak, V. E.: Circulating immune complexes after renal transplantation. Correlation of increased ${ }^{125} \mathrm{I}$ $\mathrm{Clq}$ binding activity with acute rejection characterized by fibrin deposition in the kidney. J. Clin. Invest., 60: 611 (1977).

24. Scarlett, J. A., Kistner, M. L., and Yang, L. C.: Beçhet's syndrome. Report of a case associated with pericardial effusion and cryoglobulinemia treated with Indomethacin. Am. J. Med., 66: 146 (1979).

25. Soter, N. A., Austin, K. F., and Gigli, I.: The complement system in necrotizing angiitis of the skin. Analysis of complement component activities in serum o patients with concomitant collagen-vascular disease. J. Invest. Dermatol., 63 219 (1974).

26. Stastny, P., and Ziff, M.: Cold insoluble complexes and complement levels in systemic lupus erythematosus. N. Engl. J. Med., 280: 1376 (1969).

27. Strauss, J., Koss, M., Griswold, W. R., Chernack, W., Pardo, V., and McIntosh. R. M.: Letter: cryoprecipitable immune complexes, nephropathy and sicklecell disease. Ann. Intern. Med., 81: 114 (1974).

28. Talal, N., and Pillarisetty, R. J.: IgM and IgG antibodies to DNA, RNA and DNA:RNA in systemic lupus erythematosus. Clin. Immunol. Immunopathol. 4: 24 (1976).

29. Wilson, M. R., A-royave, C. M., Miles, L., and Tan, M.: Immune reactants in cryoproteins. Ann. Rheum. Dis., 36: 540 (1977).

30. Winfield, J. B., Koffler, D., and Kunkel, H. G.: Specific concentrations of polynucleotide immune complexes in the cryoprecipitates of patients with systemic lupus erythematosus. J. Clin. Invest., 56: 563 (1975).

31. Zimmerman, S. W., Dreher, W. H., Burkholder, P. M., Goldfarb, S., an Weinstein, A. B.: Nephropathy and mixed cryoglobulinemia: evidence for an immune complex pathogenesis. Nephron, 16: 103 (1976).

32. Zinnman, H. H., and Caperton, E.: Cryoglobulinemia in a patient with Sjögren' syndrome and factors of cryoprecipitation. J. Lab. Clin, Med., 89: 483 (1977)

33. Zinnman, H. H., Levi, D., and Seal, U. S.: On the nature of cryoglobulins. J Immunol., 100: 594 (1968).

34. Zubler, R. H., Lange, G., Lambert, P. H., and Miescher, P. A.: Detection of immune complexes in unheated sera by a modified ${ }^{125} \mathrm{I}-\mathrm{Clq}$ binding test. J. Immunol., 116: 232 (1976).

35. The authors thank Dr. Charles C. August for critically reviewing the manuscript, Arlene Taylor and Karen Greenfeld for technical assistances, and Carol Sosin for preparation of the manuscript.

36. Requests for reprints should be addressed to: L. C. Yang, Ph.D., Clinical Immunology Laboratory, The Children's Hospital of Philadelphia, 34th Street and Civic Center Boulevard, Philadelphia, PA 19104 (USA).

37. This research was supported in part by the Delaware Valley Lupus Foundation

38. Received for publication April 9, 1979.

39. Accepted for publication October 22, 1979. 